7 Miller DL, Ross EM, Wadsworth J, Diamond J. Pertussis vaccine and whooping cough as risk factors for acute neurological illness in children. In: Proceedings of the fourth international symposium on pertussis, Geneva 1984, Develop Biol Stand. Vol 16, pp 389-94. S Karger, Basle, 1985.

8 Griffith AH. Permanent brain damage and pertussis vaccination: is the end of the saga in sight? Vaccine 1989;7:199-210.

9 Bowie JC. Lessons from the pertussis vaccine court trial. Lancet 1990;335: 397-9.

10 Wentz KR, Marcuse EK. DTP and serious neurologic illness: an updated review of the epidemiologic evidence. Pediatrics 1991;87:287-97.

11 Howson CP, Howe CJ, Fineberg HV, eds. Adverse effects of pertussis and rubella vaccines. A report of the Committee to Review the Adverse Consequences of Pertussis and Rubella Vaccines, Division of Health Promotion and Disease Prevention, Institute of Medicine. Washington, DC: National Academy Press, 1991:65-124.

12 Bellman MH, Rawson NSB, Wadsworth J, Ross EM, Cameron S, Miller DL. A developmental test based on the STYCAR sequences used in the nationa childhood encephalopathy study. Child Care Health Dev 1985;11:309-23.

13 Madge N, Diamond J, Miller D, Ross E, McManus C, Wadsworth J, et al

The national childhood encephalopathy study: a ten year follow-up. The national childhood encephalopathy
Dev Med Child Neurol 1993;suppl 68:1-118.

14 Raven JC, Court JH, Raven J. Manual for Raven's progressive matrices and vocabulary scales. Section 3: standard progressive matrices. London: H K Lewis, 1983

15 Raven JC, Court JH, Raven J. Manual for Raven's progressive matrices and vocabulary scales. Section $5 A$ : the Mill Hill vocabulary scale. London: $\mathrm{H} \mathrm{K}$ Lewis, 1982.

16 Vernon PE. Graded word spelling test. Sevenoaks: Hodder and Stoughton 1977.

17 Brimer A. Wide-span reading test manual. Windsor: NFER Nelson, 1984.
18 Vernon PE, Miller KM. Graded arithmetic-mathematics test: manual of instructions. Sevenoaks: Hodder and Stoughton, 1976.

19 Rutrer M. A children's behaviour questionnaire for completion by teachers: preliminary findings. F Child Psychol Psychiatry 1967;8:1-11.

20 Rutter M, Tizard J, Whitmore K. Education, health and behaviour. London: Longman, 1970.

21 Bellman MH, Ross EM, Miller DL. Infantile spasms and pertussis immunisation. Lancet 1983;i:1031-4.

22 Miettenen OS. Estimation of relative risk from individually matched series. Biometrics 1970;26:75-86.

23 Miller DL, Wadsworth J, Ross EM. Severe acute neurological illness: further analyses of the British national childhood encephalopathy study. Tokai Exp Clin Med 1988;13(suppl):145-55.

24 Miller DL, Wadsworth J, Ross EM. Pertussis vaccine and severe acute neurological illnesses: response to a recent review by members of the NCES team. Vaccine 1989;7:487-9.

25 Miller DL Wadsworth J, Ross EM. Safety of pertussis vaccine. Lancet 1990;335:655-6.

26 Fine PEM, Chen RT. Confounding in studies of adverse reactions to vaccine. Am f Epidemiol 1992;136:121-35.

27 Gale JL, Thapa PB, Bobo JR, Wassilak SGF, Mendelman PM, Foy HM. Acute neurological illness and DTP: report of a case-control study in Washington and Oregon. In: Manclark CR, ed. Sixth international symposium on pertussis, abstracts. Bethesda, Maryland: Department of Health and Human Services, 1990:228-9. (DHSS publication No (FDA) 90-1162.)

28 Marcuse EK, Wentz KR. The NCES reconsidered: summary of a 1989 workshop. Vaccine 1990;8:531-5.

(Accepted 24 August 1993)

\title{
Preregistration house officers in the Thames regions: changes in quality of training after four years
}

\author{
Jonathan H Gillard, Thomas H S Dent, Emma J Aarons, Helen L Crimlisk, Penelope J Smyth-Pigott, \\ Michael W N Nicholls
}

\section{Abstract}

Objective-To measure changes in the training and workload of preregistration house officers over four years.

Design-Postal questionnaire.

Setting-The Thames health regions.

Participants -1049 preregistration house officers.

Results-Response rate was $69 \%$ (725 replies). The proportion of house officers officially on duty $>83$ hours a week fell from at least $42 \%$ to $21 \%$, and the proportion officially on duty $\leqslant 72$ hours rose from no more than $9 \%$ to $40 \%$. Adequate guidance in breaking bad news increased from $25 \%$ to $46 \%$ ( $<<0.0001 ; 95 \%$ confidence interval for difference, $16.2 \%$ to $25 \cdot 8 \%$ ) and guidance in pain control increased from $36 \%$ to $46 \%(p<0.01 ; 5.0 \%$ to $15 \cdot 0 \%)$. The number of house officers attending an induction course increased from $61 \%$ to $94 \%(p<0.001 ; 28.9 \%$ to $37 \cdot 1 \%$ ). There was no change in the proportion unable to attend formal educational sessions because of clinical commitments or in levels of satisfaction with consultants' educational supervision. The median number of inpatients under house officers' care fell from 20 to 17 , but the numbers of patients clerked in an average week showed little change. House officers were less satisfied with the clinical experience their post provided (proportion dissatisfied rose from 30\% to $39 \%$; p $<0.01 ; 4.2 \%$ to $13.8 \%$ ) and less enthusiastic about recommending their post to a friend (proportion neutral or not recommending rose from $30 \%$ to $42 \%$, p $<0.0001 ; 7.9 \%$ to $16.9 \%$ ).

Conclusion-Despite progress in reducing hours of duty and providing induction courses, the training that hospitals and consultants provide for house officers is still unsatisfactory and inconsistent with the General Medical Council's recommendations.

\section{Introduction}

British medical graduates undergo a year's training in preregistration house officer posts approved for the purpose by their university before full registration with the General Medical Council allows them to take up posts providing more specialised training. In 1990 we published the results of a survey of the education and workload of preregistration house officers in the four Thames regions carried out by postal questionnaire in December 1988 and January 1989. ${ }^{1}$ Since then the GMC has published further recommendations on the training of house officers, ${ }^{2}$ the University of London has issued strict stipulations to hospitals on which tasks are inappropriate for house officers, ${ }^{3}$ and the Department of Health has set out a programme to reduce the hours of work of doctors in training. ${ }^{4}$ In this paper we report the changes in the quality of training of house officers in the Thames regions since our first survey.

\section{Method}

The survey was conducted by postal questionnaire. To ensure comparability of the results the second survey followed closely the method of the first. After a pilot study we wrote to all 1049 house officers in the Thames regions telling them about the survey and asking for their participation. The first questionnaires were addressed to individual house officers and distributed through clinical tutors in late November 1992. Non-responders were followed up through the tutors in early January 1993, but the response rate was less than $50 \%$. A third questionnaire was sent to nonrespondents at the address they had used when registering with the GMC. This last step had not been necessary in 1988-9.

The questionnaire requested information on the respondents' undergraduate medical education, induction courses, formal educational meetings, educational supervision, hours of duty, workload, attitude to their posts, and whether they would recommend the post to a friend. These questions were identical to those asked in the first survey, except for those about out of hours duties. Space was provided in each section for comments. Copies of the questionnaire are available from the authors. Data analysis was by 
Pearson's $\chi^{2}$ test and Fisher's exact test unless otherwise stated. The data presented here are part of a survey that also covered other aspects of the preregistration year and was sent to a sample of house officers throughout England.

\section{Results}

We received 725 returned questionnaires, a response rate of $69 \%$. The response rate in $1988-9$ was $70 \%$. The response rates from the four regions did not differ significantly. Not all respondents answered every question. Of the respondents, $372(51 \%)$ were male; $359(50 \%)$ were house physicians and $366(50 \%)$ were house surgeons. These results do not differ significantly from the first survey.

\section{PREVIOUS EDUCATION AND INDUCTION COURSES}

House officers were asked whether they had ever received adequate guidance on several important areas of practice. Table I shows the results from both surveys. There have been significant improvements in the prevalence of adequate guidance in breaking bad news $\left(\chi^{2}=73.3, p<0.01\right)$ and in pain control $\left(\chi^{2}=14.9\right.$, $p<0.01)$. If respondents in 1988-9 were predominantly referring to basic cardiopulmonary resuscitation in answering this question, the results in table I indicate that adequate guidance in this procedure has become more common. However, there has been a small and non-significant fall in the numbers of house officers confident in performing this procedure (table II).

A total of 675 of 717 house officers (94\%) had attended at least one induction course, a large increase since $1988-9$, when $414 / 679(61 \%)$ had attended at least one. The level of satisfaction with the induction course attended increased slightly: the mean score on a five

TABLE I-Satisfaction of house officers with guidance in important areas of practice

\begin{tabular}{lcc}
\hline & $\%(\mathrm{No})$ receiving adequate guidance \\
\cline { 2 - 3 } & $1988-9$ & $1992-3$ \\
\hline Breaking bad news & $25(179)$ & $46(334)$ \\
$\begin{array}{l}\text { Pain control } \\
\text { Cardiopulmonary resuscitation: }\end{array}$ & $36(262)$ & $46(331)$ \\
$\begin{array}{l}\text { Basic } \\
\text { Advanced }\end{array}$ & $82(603)^{\star}$ & $91(657)$ \\
& & $59(428)$ \\
\hline
\end{tabular}

„Not divided into "basic" and "advanced" in 1988-9.

TABLE II-Confidence with which house officers approach basic cardiopulmonary resuscitation. Figures are percentages (numbers) of respondents

\begin{tabular}{|c|c|c|}
\hline & $\begin{array}{c}1988-9 \\
(n=731)\end{array}$ & $\begin{array}{c}1992-3 \\
(n=722)\end{array}$ \\
\hline $\begin{array}{l}\text { Confident in performing unsupervised } \\
\text { Would "have a go" unsupervised } \\
\text { Would not perform unless adequately }\end{array}$ & $\begin{array}{l}66(482) \\
31(226)\end{array}$ & $\begin{array}{l}62(447) \\
37(268)\end{array}$ \\
\hline supervised & $3(23)$ & $1(7)$ \\
\hline
\end{tabular}

TABLE II-Frequency of house officers' attendance at educational meetings in week before responding to questionnaire. Figures are percentages (numbers) of respondents

\begin{tabular}{|c|c|c|c|c|c|c|c|c|}
\hline \multirow[b]{3}{*}{ Type of meeting } & \multicolumn{6}{|c|}{ Attendance } & & \\
\hline & \multicolumn{2}{|c|}{ None } & \multicolumn{2}{|c|}{$\geqslant 1$ Hour } & \multicolumn{2}{|c|}{$<1$ Hour } & \multicolumn{2}{|c|}{ Total No attending } \\
\hline & $1988-9$ & $1992-3$ & $1988-9$ & $1992-3$ & $1988-9$ & $1992-3$ & $1988-9$ & $1992-3$ \\
\hline $\begin{array}{l}\text { Death and complications, } \\
\text { or audit } \\
\text { x Ray } \\
\text { Pathology } \\
\text { Case presentations } \\
\text { Drug lunches or meetings } \\
\text { where main speaker was } \\
\text { drug representative }\end{array}$ & $\begin{array}{l}76(541) \\
47(331) \\
78(551) \\
29(204)\end{array}$ & $\begin{array}{l}60(417) \\
36(254) \\
75(518) \\
44(311)\end{array}$ & $\begin{array}{l}21(147) \\
46(329) \\
21(147) \\
37(262)\end{array}$ & $\begin{array}{l}29(206) \\
54(382) \\
24(162) \\
43(302)\end{array}$ & $\begin{array}{c}3(22) \\
7(50) \\
1(7) \\
35(249)\end{array}$ & $\begin{array}{c}11(76) \\
10(69) \\
1(9) \\
14(96)\end{array}$ & $\begin{array}{l}710 \\
710 \\
705 \\
715\end{array}$ & $\begin{array}{l}699 \\
705 \\
689 \\
709\end{array}$ \\
\hline
\end{tabular}

«The 1988-9 survey asked about death and complication meetings, the 1992-3 survey about audit meetings.
TABLE IV-House officers' satisfaction with quality of formal educational meetings

\begin{tabular}{lcc}
\hline & \multicolumn{2}{c}{$\%$ (No) of respondents } \\
\cline { 2 - 3 } & $\begin{array}{c}1988-9 \\
(\mathrm{n}=669)\end{array}$ & $\begin{array}{c}1992-3 \\
(\mathrm{n}=683)\end{array}$ \\
\hline 1 Very satisfactory & $12(78)$ & $8(56)$ \\
2 [Satisfactory] & $37(248)$ & $36(247)$ \\
3 [Neutral] & $36(242)$ & $40(276)$ \\
4 [Unsatisfactory] & $13(84)$ & $12(81)$ \\
5 Very unsatisfactory & $3(17)$ & $3(23)$ \\
\hline Mean (SD) & $2.57(0.94)$ & $2.66(0.91)$ \\
\hline
\end{tabular}

* Subjective scale.

$\chi^{2}$ For trend $=3.04, \mathrm{df}=4, p=0.081$.

TABLE V-Frequency with which clinical commitments prevented house officers from attending formal educational meetings

\begin{tabular}{lcc}
\hline & \multicolumn{2}{c}{$\%(\mathrm{No})$ of respondents } \\
\cline { 2 - 3 } & $\begin{array}{c}1988-9 \\
(\mathrm{n}=725)\end{array}$ & $\begin{array}{c}1992-3 \\
(\mathrm{n}=707)\end{array}$ \\
\hline 1 Not at all & $6(44)$ & $6(43)$ \\
2 [Rarely] & $16(119)$ & $15(109)$ \\
3 [Sometimes] & $31(223)$ & $33(232)$ \\
4 [Often] & $26(188)$ & $31(222)$ \\
5 Almost invariably & $21(151)$ & $14(101)$ \\
\hline Mean (SD) & $3.39(1.16)$ & $3.32(1.09)$ \\
\hline
\end{tabular}

*Subjective scale.

$\chi^{2}$ For trend $=1 \cdot 25, \mathrm{df}=4, \mathrm{p}=0 \cdot 26$.

point scale ranging from 1 (very satisfied) to 5 (very dissatisfied) in 1988-9 was 3.30 (SD 1.06) and in 1992-3 was $3.05(0.943)$ ( $\chi^{2}$ for trend $\left.=18 \cdot 1, \mathrm{df}=4, \mathrm{p}<0.0001\right)$.

FORMAL EDUCATIONAL MEETINGS AND EDUCATIONAL SUPERVISION

House officers were asked how much time in the previous week they had spent at various types of educational meetings. Table III shows the results.

In 1988-9, 389/725 house officers (54\%) said there were enough formal educational meetings at their hospitals; in 1992-3, 374/713 (52\%) said so. There was also little change in house officers' views on the quality of the meetings and the tendency of their clinical commitments to keep them from attending the meetings (tables IV and V). One house officer commented, "Five out of six audit meetings I was on call and therefore could not attend."

Similarly, the satisfaction of house officers with their educational supervision has not improved. The GMC recommends that the consultant responsible for training a house officer should personally carry out the following functions (among others) ${ }^{2}$ :

(a) discuss and provide written records of the house officer's duties and availability of cover and supervision;

(b) regularly and informally monitor and discuss progress and problems in time set aside for the purpose; and

(c) ensure that the house officer receives career guidance.

House officers' opinions on the performance of their consultants in these tasks are shown in table VI.

HOURS OF WORK

A total of 702 of $722(97 \%)$ of house officers were working an on call rota, $11(2 \%)$ a partial shift, and five $(1 \%)$ a full shift. The $1988-9$ survey asked about the type of on call rota contracted (for example, one in three), whereas the 1992-3 survey asked about official hours on duty in an average week (table VII). The mean total hours of work on a day without on call duties were $9 \cdot 2(1 \cdot 25)$ hours. This compares with 19889 , when the equivalent result (the difference between average starting and finishing times) was $9 \cdot 6$ hours. 
TABLE VI-House officers' satisfaction with specified educational responsibilities of consultant

\begin{tabular}{|c|c|c|c|c|c|c|}
\hline & \multicolumn{6}{|c|}{$\%(\mathrm{No})$ of respondents } \\
\hline & \multicolumn{2}{|c|}{$\begin{array}{c}\text { Discussion at } \\
\text { beginning of post }\end{array}$} & \multicolumn{2}{|c|}{$\begin{array}{l}\text { Discussion during } \\
\text { post }\end{array}$} & \multicolumn{2}{|c|}{$\begin{array}{l}\text { Provision of career } \\
\text { information }\end{array}$} \\
\hline & $\begin{array}{c}1988-9 \\
(\mathrm{n}=727)\end{array}$ & $\begin{array}{c}1992-3 \\
(n=718)\end{array}$ & $\begin{array}{c}1988-9 \\
(n=726)\end{array}$ & $\begin{array}{c}1992-3 \\
(n=717)\end{array}$ & $\begin{array}{c}1988-9 \\
(\mathrm{n}=711)\end{array}$ & $\begin{array}{c}1992-3 \\
(n=715)\end{array}$ \\
\hline $\begin{array}{l}1 \text { Very satisfactory } \\
2 \text { [Satisfactory] } \\
3 \text { [Neutral] } \\
4 \text { [Unsatisfactory] } \\
5 \text { Very unsatisfactory }\end{array}$ & $\begin{array}{c}9(67) \\
19(135) \\
30(215) \\
25(180) \\
18(130)\end{array}$ & $\begin{array}{c}9(67) \\
21(153) \\
24(172) \\
27(196) \\
18(130)\end{array}$ & $\begin{array}{l}14(99) \\
22(163) \\
27(199) \\
23(167) \\
14(98)\end{array}$ & $\begin{array}{l}13(90) \\
23(163) \\
27(193) \\
25(181) \\
13(90)\end{array}$ & $\begin{array}{c}7(50) \\
17(123) \\
25(176) \\
27(194) \\
24(168)\end{array}$ & $\begin{array}{c}9(63) \\
19(136) \\
24(173) \\
25(175) \\
24(168)\end{array}$ \\
\hline $\operatorname{Mean}(S D)^{\star}$ & $3 \cdot 24(1 \cdot 21)$ & $3.24(1.24)$ & $3.00(1.24)$ & $3.03(1.22)$ & $3.43(1.22)$ & $3.35(1.27)$ \\
\hline
\end{tabular}

^Subjective scale.

Discussion at beginning of post: $\chi^{2}$ for trend $=0.00, \mathrm{df}=4, \mathrm{p}=1 \cdot 0$

Discussion during post: $\chi^{2}$ for trend $=0.18, \mathrm{df}=4, p=0.73$.

Provision of career information: $\chi^{2}$ for trend $=1 \cdot 61, \mathrm{df}=4, \mathrm{p}=0.21$.

TABLE VII-Total weekly hours on duty for house officers on rotas

\begin{tabular}{lcc}
\hline & \multicolumn{2}{c}{$\%$ (No) of respondents } \\
\cline { 2 - 3 } Hours on duty & $\begin{array}{c}1988-9^{\star} \\
(\mathbf{n}=725)\end{array}$ & $\begin{array}{c}1992-3 \\
(\mathbf{n}=700)\end{array}$ \\
\hline$<60$ & $4(8)$ & $4(27)$ \\
$60-71$ & $\int^{8}$ & $12(82)$ \\
72 (equivalent to 1 in 4$)$ & $16(114)$ & $24(164)$ \\
$73-82$ & $33(240)$ & $31(215)$ \\
83 (equivalent to 1 in 3$)$ & $33(242)$ & $9(63)$ \\
$84-95$ & $9(65)$ & $19(134)$ \\
$>95$ & $2(15)$ \\
\hline$x^{2}$ For trend & &
\end{tabular}

$\chi^{2}$ For trend $=244, \mathrm{df}=5, \mathrm{p}<0.0001$.

${ }^{\star}$ Results for $1988 / 9$ ignore early starts and late finishes.

WORKLOAD

The median number of inpatients that house officers had under their care at the time they completed our questionnaire fell from 20 (range 1-60; interquartile range $15-25)$ in $1988-9$ to $17(1-80 ; 13-24)$ in 1992-3. The reduction in the number of patients is significant (Mann-Whitney $U$ test, $p<0.001$ ). The numbers caring for more than 30 patients (suggested previously by the GMC as a maximum for adequate training ${ }^{5}$ ) and with fewer than 10 patients are shown in table VIII.

The median numbers of patients clerked by house officers in an average week showed little change in any category: emergency, $10(1988-9,10)$; routine, 6 (7); day, 4 (4); and outpatient, 3 (4). Respondents were also asked the numbers of patients clerked in quiet and busy weeks; these results are not included but the question may have reduced any tendency to exaggerate the report for an average week.

TABLE VIII-Number of inpatients under house officers' care

\begin{tabular}{lcc}
\hline & \multicolumn{2}{c}{$\%(\mathrm{No})$ of respondents } \\
\cline { 2 - 3 } & $\begin{array}{c}1988-9 \\
(\mathrm{n}=733)\end{array}$ & $\begin{array}{c}1992-3 \\
(\mathrm{n}=720)\end{array}$ \\
\hline$<10$ & $7(51)$ & $9(68)$ \\
$10-30$ & $83(606)$ & $83(599)$ \\
$>30$ & $10(76)$ & $7(53)$ \\
\hline
\end{tabular}

TABLE IX-House officers' opinions on clinical experience provided by their patients

\begin{tabular}{lcc}
\hline & \multicolumn{2}{c}{$\begin{array}{c}\%(N o) \text { of } \\
\text { respondents }\end{array}$} \\
\cline { 2 - 3 } & $\begin{array}{r}1988-9 \\
(\mathrm{n}=740)\end{array}$ & $\begin{array}{c}1992-3 \\
(\mathrm{n}=701)\end{array}$ \\
\hline $\begin{array}{l}\text { Gaining about the right amount of clinical experience } \\
\begin{array}{l}\text { Seeing too few patients to gain sufficient clinical } \\
\text { experience }\end{array}\end{array}$ & $70(517)$ & $61(429)$ \\
$\begin{array}{l}\text { Seeing so many patients that there is no time to learn } \\
\text { from the post }\end{array}$ & $14(107)$ & $18(123)$ \\
\hline$\chi^{2}=12 \cdot 4, \mathrm{df}=2, \mathrm{p}<0.01$. & $16(116)$ & $21(149)$ \\
\hline
\end{tabular}

Table IX shows house officers' increasing dissatisfaction with the effect of patient numbers on their clinical training $\left(\chi^{2}=12 \cdot 4, \mathrm{df}=2, \mathrm{p}<0.01\right)$.

The number of house officers expected to provide care for private patients showed little change (406/728 $(56 \%)$ in $1988-9,375 / 720(52 \%)$ in $1992-3 ; \chi^{2}=1.83$, $\mathrm{df}=1, \mathrm{p}=0 \cdot 18)$. The proportion of those doing this work who expected to be paid remained low (38/396 $(10 \%)$ in $1988-9,47 / 373(13 \%)$ in $1992-3 ; \chi^{2}=2 \cdot 75, \mathrm{df}=$ $1, p=0 \cdot 1)$. Not all those caring for private patients answered the question about payment.

\section{ATTITUDE TO POST}

The final question asked house officers how much they would encourage or discourage a friend who was considering applying for their post. Respondents in 1992-3 were less encouraging (table $\mathrm{X} ; \chi^{2}$ test for trend $=19.6, d f=4, p<0.0001)$. Some valued their training highly; one said, "Generally I enjoyed general surgery very much," but others were very bitter: "Whether I recommended my post would depend on how masochistic the friend is, how much they value their physical and mental health ... and whether they could cope with seeing their own personalities change from being lively, fun loving, and inquisitive to being a washed out, disillusioned, cynical automaton."

TABLE X-Extent to which house officers would encourage or discourage friends to apply for their post

\begin{tabular}{|c|c|c|}
\hline & \multicolumn{2}{|c|}{$\%$ (No) of respondents } \\
\hline & $\begin{array}{c}1988-9 \\
(n=726)\end{array}$ & $\begin{array}{c}1992-3 \\
(n=715)\end{array}$ \\
\hline $\begin{array}{l}1 \text { Strongly encourage } \\
2 \text { [Encourage] } \\
3 \text { [Neutral] } \\
4 \text { [Discourage] } \\
5 \text { Strongly discourage }\end{array}$ & $\begin{array}{l}29(210) \\
41(298) \\
20(145) \\
6(45) \\
4(28)\end{array}$ & $\begin{array}{l}25(178) \\
33(238) \\
24(171) \\
12(86) \\
6(42)\end{array}$ \\
\hline $\operatorname{Mean}(S D)^{\star}$ & $2.15(1.03)$ & $2.41(1 \cdot 16)$ \\
\hline
\end{tabular}

* Subjective scale.

$\chi^{2}$ For trend $=19 \cdot 6, \mathrm{df}=4, \mathrm{p}<0 \cdot 0001$.

\section{Discussion}

PREVIOUS EDUCATION AND INDUCTION COURSES

The improvement in house officers' training in pain control and breaking bad news is probably due to the greater emphasis on these topics in undergraduate training. More than half of house officers, however, still do not believe themselves adequately trained in these areas of their everyday work. House officers commonly identify these as important skills which they lack, ${ }^{6}$ and the GMC sees the preregistration year as a time to develop these skills by specific training. Garrud found that problems with breaking bad news were a common reason for senior house officers needing counselling. ${ }^{\text {? }}$

Induction courses are stipulated by the GMC as part of a house officer's training. Their near universal use without loss in quality indicates greater recognition of their importance and knowledge of how to make best use of them. ${ }^{8}$ However, there are limits to what can be achieved: one house officer remarked, "It is impossible for an induction course to be adequate, given how inadequate medical school is at preparing medical students to be house officers."

An apparent increase in the adequacy of training in basic cardiopulmonary resuscitation has been accompanied by little change in the proportion confident in performing it. It has been shown that confidence and competence in this activity do not always coincide. ${ }^{9}$ More adequate training may produce a rise in competence but not remove anxiety about the procedure; hence house officers still lack confidence. 


\section{Educational implications}

- House officers are generally satisfied with the quality of their formal educational meetings, but clinical commitments often prevent them from attending

- As well as induction courses, training in pain control and breaking bad news are more widespread, but more than half of house officers still lack adequate training in these areas

- Hours of duty have been cut but not enough to achieve "new deal" targets

- House officers have fewer patients under their care and are less satisfied with their clinical experience, and they have become less enthusiastic about recommending their posts

\section{HOURS OF WORK}

We assumed that house officers in 1988-9 reported their contracted duty rotas without including the effect of early starts and late finishes. They reported whether they had prospective cover and we included that in calculating their hours on duty. We assumed that house officers in 1992-3 included early starts, late finishes, and the effects of prospective cover in reporting "official hours on duty." This assumption is supported by the high proportion reporting hours other than those produced by conventional one in three or one in four rotas. The assumption about 1988-9 respondents tends to reduce the apparent extent of change since then, while that about 1992-3 tends to exaggerate it. The NHS Management Executive has indicated that early starts, late finishes, and prospective cover should be included in calculating hours on duty. ${ }^{4}$

The reduction in house officers' hours of duty is impressive. The proportion of house officers officially on duty for more than 83 hours a week has fallen from at least $42 \%$ to $21 \%$, and the proportion officially on duty for 72 hours or less has risen from no more than $9 \%$ to $40 \%$. We do not know to what extent the reduction in hours has been achieved at the expense of increasing intensity of work.

\section{ATTITUDE TO POST}

Despite a small fall in the average numbers of patients under their care, there has been an increase in the number of house officers reporting such pressure of work that they cannot learn effectively. The median number of patients under the care of house officers reporting this degree of overwork has fallen from 24 to 22 . The median number of patients under the care of those gaining the right subjective amount of clinical experience has also fallen, from 20 to 18 . However, the number of house officers with too few patients is increasing, and those in this group are caring for slightly more patients than before, the median rising from 13 to 14 . By contrast, the total number of admissions (routine, emergency, and day case) reported by each group has changed little over the four years.

The number of patients admitted in a week has not changed, suggesting that the fall in inpatient numbers is a result of reduced lengths of stay. The greater complexity of routine medical care, briefer admissions, and increasing emphasis on the educational purpose of the preregistration year seem to be making house officers more aware of the opportunities they are missing. This may partly explain the large rise in the proportion of house officers with a negative view of the desirability of their post.

\section{CONCLUSION}

Great attention has been paid in the past few years to improving the lot of junior hospital doctors, especially those who are most vulnerable to erosion of their training, morale, and quality of life by excessive and inappropriate clinical demands. This survey shows that progress can be and has been made in improving the educational quality of house officer posts when there is wholehearted commitment from doctors and managers. The reduction in hours on duty and the spread of induction courses to nearly every post is impressive, and the greater concentration on training in communication skills and pain control is welcome. But there is still much work ahead. The training of house officers depends on protection from encroachment by often inappropriate clinical work, and until this is provided the aspirations of the GMC will remain of little relevance. Postgraduate deans can now withhold from hospitals up to half the salary of doctors in training. This is a more flexible and credible negotiating device than the withdrawal of university recognition, the only sanction previously available when house officer training was persistently neglected. Hospitals will now be helped to see that the opportunity to use junior doctors' labour at a subsidised rate is acquired at the price of offering them satisfactory training. We hope and expect that progress will continue, for the sake of all the house officers who would echo the plaintive line at the end of one questionnaire: "I love medicine but hate being abused."

We are grateful to the house officers who completed our questionnaire; to the clinical tutors and their staff who distributed it; to Professor Peter Flute and Drs Elizabeth Shore and Jack Tinker who gave us permission to survey their regions; to Julie DeSimon, who coordinated the fieldwork; and to Dr R C King, who inspired these projects. We are also grateful to Julian Lipscombe for data entry.

1 Dent THS, Gillard JH, Aarons EJ, Crimlisk HL, Smyth-Pigott PJ. Preregistration house officers in the four Thames regions. I. Survey of education and workload. $B M Y$ 1 1990;300:713-6.

2 General Medical Council. Recommendations on general clinical training. London: GMC, 1992.

3 University of London. The preregistration year: inappropriate duties for preregistration house officers. London: University of London, 1990.

4 NHS Management Executive. Funior doctors: the new deal. London: NHSME, 1991.

5 General Medical Council. Recommendations on general clinical training. London: GMC, 1987.

6 Calman KC, Donaldson M. The preregistration house officer year: a critical incident study. Med Educ 1991;25:51-9.

7 Garrud P. Counselling needs and experience of junior hospital doctors. BMF 1990;300:445-7.

8 Gale R, Jackson G, Nicholls $M$. How to run an induction meeting for house officers. $B M{ }^{\prime}$ 1992;304:1619-20.

9 Marteau TM, Wynne G, Kaye W, Evans TR. Resuscitation: experience without feedback increases confidence but not skill. $B M \mathcal{F}$ 1990;300:849-51.

(Accepted 26 August 1993)

\section{Correction}

Risk factors for development of flucloxacillin associated jaundice

An authors' error occurred in this paper by Christopher K Fairley and others (23 January, pp 233-5). In table II the male to female ratio was reversed. It should be 22 to 29 in cases and 113 to 86 in controls. 